International Journal of Linguistics, Literature and Culture
Available online at https://sloap.org/journals/index.php/ijllc/
Vol. 6, No. 1, January 2020, pages: 1-13
$\begin{aligned} & \text { ISSN: 2455-8028 } \\ & \text { https://doi.org/10.21744/ijllc.v6n1.795 }\end{aligned}$

\title{
Bridging the Gap between Translation and Culture: Towards a Cultural Dimension of Translation
}

Bakr Bagash Mansour Ahmed Al-Sofi a Hassan Abouabdulqader ${ }^{b}$

Article history:

Received: 09 September 2019

Accepted: 18 November 2019

Published: 09 January 2020

Keywords:

bicultural;

bilingual;

culture;

intercultural communication;

translation;

\begin{abstract}
This study investigates the significance of culture in the translation process. It tackles the prior call that being bilingual is enough for translation, neglecting the importance of culture for creative translation. This descriptive and analytical study is based on the semantic approach, following Ghazala's (2008) and Nida's (1964) theories of translation. It depends on textual analysis of culturally-laden collocations in some common terms, expressions, idioms, and proverbs. It was confirmed that culture is at the heart of translation as the two are inextricably interdependent. Furthermore, successful translation necessarily entails a profound understanding of the cultural context of the text, which leads to the successful transmission of the intended meaning. It is recommended that the traditional approach that bilingualism is enough for good translation should be reconsidered, and that translation programs designers and translators should give culture its due place in the translation process.
\end{abstract}

International journal of linguistics, literature and culture (C) 2020.

This is an open access article under the CC BY-NC-ND license (https://creativecommons.org/licenses/by-nc-nd/4.0/).

\section{Corresponding author:}

Bakr Bagash Mansour Ahmed Al-Sofi,

Assistant Professor of English, College of Sciences and Arts in Al-Namas,

University of Bisha, Kingdom of Saudi Arabia.

Email address: bbmansour@ub.edu.sa

\footnotetext{
a University of Bisha, Kingdom of Saudi Arabia

b Sanderland Institute of Science and Technology (SIST), Rabat, Morocco
} 


\section{Introduction}

In the second half of the $20^{\text {th }}$ century, Translation Studies (TS) was developed as an independent academic discipline that can stand alone. The existence of a plethora of theories of translation is itself a recognition that the field of translation encompasses a variety of dimensions (Pym, 2010). It has become a more prolific, more visible and more respectable activity than perhaps ever before, with great input from cultural studies. Schaffner (2003), clarified that the "recognition of the complexity of the phenomenon of translation means that it is widely accepted nowadays that TS is an independent discipline in its own right (and not a sub-discipline of applied linguistics, or of comparative literature, as often argued in the past)" (p. 86). The extended notion of translation as an interdisciplinary domain has gone beyond providing equivalence towards "preserving semantic and stylistic equivalences" (Bell, 1991) and conveying the intended meaning of the source text, taking into account the source and target cultures.

It is worth casting light on the importance of culture to the translation process since it has gained prominence and has become a widely discussed argument nowadays. Bell (1991), for example, defined translation competence as "the knowledge and skills the translator must possess in order to carry out a translation" (Orozco \& Albir, 2002). It is described as a "complex concept that requires knowledge of two or more languages and usually consists of two or more sub-competencies" (Šeböková, 2010). It refers that translation has to do more with performance than with competence as the latter is an abstract concept (knowledge) that can only be measured and evaluated in performance (translating). Therefore, in order to reach good translation, translators need to work competently and reliably in different domains.

This study acknowledges Nida (1964) and Ghazala (2008), notable contributions to translation as they are among the most influential theories of translation, especially that they focus on rendering linguistic and cultural characteristics of the source text into the target text. Nida (1964) confirmed that "differences between cultures may cause more serious problems for the translator than do differences in language structure". He approached the translation process from two perspectives: the formal equivalence and the dynamic one. In the formal equivalence, the translator conveys the form and content of the source text as it is to the target text. On the other hand, in the dynamic (functional) equivalence, the translator renders the source text honestly paying attention to its meaning, cultural equivalence, and rendering its effect into the target text. In this sense, the translator should find not only the equivalents of words but also the equivalents of the intention and aims of the author, who represents at the same time the knowledge and culture of his/her context. In the same vein, Hassan (2014) maintained that "cultural elements are more resistant to translation than linguistic ones (p. 6). This conception accords with Ghazala (2008), a standpoint that the translator can go "outside texts and out of contexts, behind and beyond words and phrases, looking perhaps for the spirit, or the message. He can translate something the way he understands it. His way of understanding is confined by text and context variable to some or great extent" (p. 12). What is needed, accordingly, is a more genuine, functional and pragmatic view that gives the socio-cultural dimension its due.

With this background, the current study aims to bridge the cultural gap in translation by investigating the role of culture in the success of the translation process. It is conducted as it has been taken for granted that being bilingual is enough for successful translation, overlooking the effective role of culture in the translation process. Hence, it is hypothesized that culture bridges the gap in translation in which cultural aspects of the source text should be conveyed to the target one. The present study employs the descriptive and analytical approach depending on textual analysis of common terms, expressions, idioms, and proverbs, supported by culturally-oriented examples from Arabic and English.

\section{Review of the Literature}

Central in the conception of translation, as used in the present study is that its basic foundations need to be entrenched in the socio-cultural dimension of communication. As detailed below, these two dimensions constitute the theoretical framework of the study.

\section{Translation and Culture}

Since language reflects the culture and an integral part of it, the process of translation cannot be carried out without integrating the cultural cues in the construction of meaning. Hassan (2014), stated that a good translation "is one that carries all the ideas of the original as well as its structural and cultural features" (p. 2, italics is added). In this sense, culture is regarded as non-linguistic aspects of traditions, values, beliefs, behaviors, etc. and how they are expressed 
in the source text and conveyed to the target text. With the passage of time, understanding the "cultural value of a translation text has grown deeper, especially in respect to the importance of translations for the identity of the receiving culture" (Torop, 2002; Muamaroh, 2008; Sugyaningsih \& Mardiana, 2017). Bearing the same idea, Salehi (2012), acknowledged that culture and translation are among the most determining and influential variables in human communication. This fundamental concept has gained obvious importance in the field of TS.

Hermans (1999), advocated that translation should be recognized as a cultural practice. It is a kind of linguisticcultural activity which involves at least two languages and two cultural traditions. Likewise, House (2014), asserted that translation is not only a linguistic act; it is also a cultural one, an act of communication across cultures. Later, Hassan (2014) emphasized that a good translation "is one that carries all the ideas of the original as well as its structural and cultural features" and that "reconstructs the cultural/historical context of the original" (p. 2). These opinions ascertain that there is an interaction between culture and translation. In other words, translation activity is no longer simply a matter of seeking other words with similar equivalence, as equivalence is relative, but indeed the whole language and culture in which the text is constituted should be highlighted. Torop (2002), equated culture with translation in the sense that "culture is the translation, and also that translation is culture" (p. 603). Similarly, Muamaroh (2008), maintained that "translation is the process of transferring not only the message but also the style and the culture from the source language to target one" (p. 150). It implies that translation is strongly grounded in its cultural context. Skopos theory indicated that cultural and linguistic competence means that "translators are the ones who decide on what to translate and, when and how to do that. Translators can achieve that goal through the knowledge about the source and the target culture and language. Linguistic deficiencies in the translation may be acceptable in a way but the ones related to culture are not approved" (Yaz1c1, 2007). Such a theory that depends on the functionalist approach concentrates on the communicative aim of translation. Similarly, Ghazala (2008), asserted that meaning is not only in words but it is also in culture, grammar, style, and sound. Recently, Hassan (2014) asserted that "the more a translator is aware of differences between cultures, the better a translator s/he will be" (p.48). Consequently, competent translators should strive to grasp the intended meaning of the original text and be aware of the various cultural aspects in order to overcome the culture-bound issues.

Newmark (2001), clarified that culture in translation competence is "the greatest obstacle to translation, at least to the achievement of an accurate and decent translation" (p. 328). What is fundamental in translation is "to preserve and control the original meaning when it is conveyed or converted into the target language's verbal expression" (Darwish, 2001). Similarly, Pym (1992), maintained that there are "many ways of translating, many things that can be said through translation" (Darwish, 2001; Suryasa et al., 2019). Likewise, Ghazala (2008), emphasized that "we translate meaning, nothing else but meaning" (p. 3). Interestingly, Bassnett \& Lefevere (1990) asserted that "neither the word nor the text" but culture should be the unit of translation" (p. 8). Bearing in mind the widespread consensus among researchers regarding the importance of culture in translation, the translation activity is a question of transferring the accurate meaning and that the translator has an effective role in transferring not only the linguistic system of the source text but also the cultural one. As such, it is extremely difficult to draw a borderline between translation and culture as they are inextricably overlapped and this connection leads to creative translation.

\section{Translation and Intercultural Communication}

First, it is worth noting that the notion of communication has had a lot of impact on TS. As reported in current research, the translation process has gained great value since it has made intercultural communication one of its components (Bell, 1991; Byram \& Risager, 1999; Fenyo, 2005; House, 2014; Komissarov, 1991; Schäffner, 2003; Liu, 2018). AlQurashi (2004), asserted that translation has been of great importance to all nations as it plays an essential role in imparting knowledge from one culture to another. Gerding-Salas (2000) also maintained that the main aim of translation is to serve as a cross-cultural bilingual communication vehicle among people of different tongues and cultures. Similarly, Komissarov (1991) stated that translation brings to the receptors "new facts and ideas inherent in the source language culture, broadens their cultural horizons, makes them aware that other people may have different customs, symbols, and beliefs, that other cultures should be known and respected" (p. 46). Within this trend, translators are regarded as "mediators between two cultures, not merely two languages" (Hatim \& Mason, 1990). In the same vein of thought, Byram \& Risager (1999), revealed that the ability to mediate between two cultures is an essential component of intercultural competence. Supporting this idea, Wafa (2014), stated that as a translator, "you need to understand the culture of the audience you are communicating with. You are standing as a mediator between the SL and TL" (p. 35). In this sense, the translator should be well versed in the source and target cultures.

Al-Sofi, B. B. M. A., \& Abouabdulqader, H. (2020). Bridging the gap between translation and culture: towards a cultural dimension of translation. International Journal of Linguistics, Literature and Culture, 6(1), 1-13. 
Obviously, translation and intercultural communication share common features in which the translator plays a crucial role as an effective intercultural mediator by exchanging knowledge across cultures. It denotes that the source text should be linked with its cultural context as it is produced for the demands of others in various intercultural situations. To sum up, translation is equated with intercultural communication as the two are associated with different cultural contexts. Since the translation process involves the cross-cultural transfer, "cultural knowledge is an essential part of the translator's competence" (Fenyo, 2005). Hence, it is worth pointing out that a good translation meets intercultural transmission by rendering the intended meaning and bridging the gap between the two cultures.

Bahumaid (2010), found that the informants' rather low performance in the renditions of culture-bound expressions from English into Arabic and their major types of errors involved incorrect meaning, under-translation, and omission can be attributed to their inadequate knowledge of English culture and their improper knowledge of the translation procedures employed in rendering culture-specific expressions. Similarly, Elzubier (2012), found that some programs have neglected the contrastive linguistics aspects of the two languages and cultures which show the basic variations between English and Arabic.

\section{Materials and Methods}

Essentially, the translators face linguistic and cultural problems. Hassan (2014), indicated that "problems related to cultural differences which include many extralinguistic features, such as religion, social backgrounds, unfamiliar natural phenomena, and others" (p. 49). To tackle such problems, Venuti (1995) suggested two strategies that can be used to bridge the cultural gaps in the translation process: domestication and foreignization. Consequently, this study takes into consideration Nida's and Ghazala's theories that confirm the importance of culture in the translation process and the importance of conveying the intended message. It also considers Venuti (1995), domestication and foreignization strategies that are used to bridge the cultural gaps in the translation process.

\section{Design of the Study}

This study is qualitative in nature. It employs the descriptive and analytical approaches depending on textual analysis. It refers to the cultural aspects associated with a wide range of common terms, expressions, idioms, and proverbs with culturally-oriented examples from Arabic and English. It pays special attention to their cultural aspects as they have different meanings in various cultures. A qualitative approach is suitable for TS research as it analyzes texts rather than numerals.

\section{Statement of the Problem}

Within the context under investigation, the translation process is not a straightforward or easy activity as it is assumed at first glance. Rather, it is a complicated process as cultural elements constitute a serious challenge for translators to render creative translation. In other words, general cultural differences are sometimes bigger obstacles to successful translation than linguistic ones. In this regard, this study is conducted as it has been taken for granted that being bilingual is sufficient for a good translation, paying no attention to the strong bond between language and culture in relation to translation. What is more striking is that there is a gap in which the position of culture in the success of translation has rarely brought into the discussion, especially in the Arab world. Arabs are in a crucial need of translation more than ever before in order to improve their distorted image, as drawn in the West, and reflect a real one about their identity and culture. Badawi (2008), confirmed that "the role of culture in translation is marginalized in the research in the Arab world" (p. 7). To this end, this study tries to bridge such a gap by shedding more light on the importance of cultural dimension for creative translation.

\section{Aims and Hypothesis of the Study}

This study is driven by the idea that "cultural differences have been the main issue in translation theory" (Hassan, 2014). It addresses the importance of bridging the cultural gap in the translation process. Specifically, the strong bond between culture and translation and the importance of culture for successful translation are the main investigated issues of this study. Additionally, various culturally-based examples are translated from Arabic into English and vice versa, bearing in mind the semantic approach as it is the most important element that translators need to grasp. The present 
study is based on Al-Dosari (2013), a recommendation that translators, as well as, learners should be exposed to various cultural aspects of the source and target cultures. Moreover, investigating such an argument is essential in the age of easy mobility and intercultural communication. This study is also driven by the assumption that the translation process is not only about being bilingual, but there is something that imposes itself strongly and cannot be overlooked, which is being a bicultural translator.

This study is significant as the translation has become a real-life communicative activity that is practiced almost on a daily basis. It also tries to bridge the cultural gap in the translation process and directs the stakeholders' close attention to the importance of biculturalism for creative translation. It seeks an answer to the main question: Does culture enhance creative translation or not? If yes, to what extent?

\section{Results and Discussions}

By using real-time data, the study focuses on the compilation and detailed analysis of a set of idiomatic expressions translated into Standard Arabic and regional dialects bearing in mind the involvement of cultural associations. They follow Morris's optative and imperative categorization. The first example is the Arabic expression الهَ يَعِيكَ العَافيةَ ya'atika ala'afiah/. In most of the Middle Eastern countries, it means that "May Allah grant you good health". In the Moroccan cultures, on the other hand, such association is largely mistaken as the word /ala'afiah/means 'fire'. The

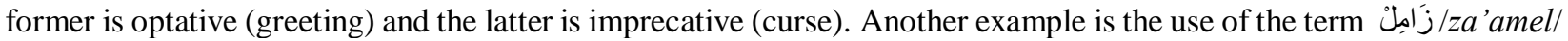
which is one of the most popular lyric activities that is practiced in Yemen and Gulf cultures on various occasions. In contrast, it is associated with 'homosexuality' in Moroccan cultures. Similarly, in the Algerian culture, it describes the person who is cowardly, weak, or wanderer. Another example, in Yemeni tribal regions, the word كَاثني /ma'asheel with strong accent means 'no'. Quite the reverse, in the African cultures, it means okay and denotes acceptance. Such examples exemplify cultural acceptability between various cultures. If there is no awareness of the differences within the Arabic subcultures, it is misunderstood and hence leads to distortion of meaning and communication breakdown.

Table 1

Examples of Arabic terms and expressions that have different associations

\begin{tabular}{llll}
\hline Arabic word & transliteration & Good association & Another association \\
\hline الهَعِيكَ العَافية & $\begin{array}{l}\text { IAllah ya'atika } \\
\text { ala'afiah/ } \\
\text { Iza'amell }\end{array}$ & $\begin{array}{l}\text { "May Allah grant you good } \\
\text { health". }\end{array}$ & "May Allah grant you fire" \\
زَامِل & Popular lyric activity & $\begin{array}{l}\text { Homosexual, cowardly, } \\
\text { weak, etc. }\end{array}$ \\
& Ima'asheel & Okay and agreement & No and disagreement \\
\hline
\end{tabular}

Kashgary (2011), clarified that Arabic is loaded with culture-specific terms and expressions that have no equivalents in English. Supporting this idea, the difficulty in translating the following terms is due to lexical gaps resulting from the cultural differences and the linguistic and cultural distance between the two languages as Arabic is a Semitic language and English is an Indo-European one. It can be said that some of the following words are foreignized bearing in mind Venuti (1995), the strategy of foreignization. For example, the Arabic term سَحُور "sahuurun/ is broadly used in Islamic cultures, especially during the fasting month of Ramadan. It refers to the food that is eaten before dawn to be ready for fasting. This term is not lexicalized and has no equivalence in the English language so paraphrasing strategy can be used to transmit its meaning. Likewise, the Arabic term مَحْرَمْ /mahramun/ has a connotative meaning in the Islamic culture, which refers to the person who should accompany his family while moving or traveling

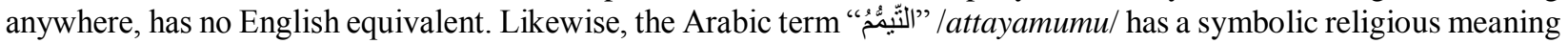
that is unknown in the English culture. It refers to dry ablution using the dust when there is no water for prayers ablution. Another example is the Arabic religious term "الأًَانُ "laladhanu/. It was translated into English as 'calling for

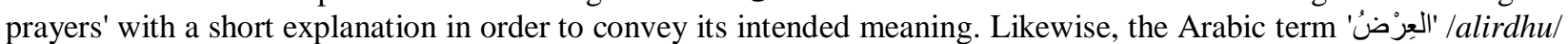
is difficult to be translated into the English term 'dignity' without using explanation or paraphrasing strategies as it does not convey its full meaning. Therefore, more paraphrasing can be added as it refers to "a male's honor in protecting female members of his family, possessions, and other people he is responsible for" (Kashgary, 2011). It is obvious from these Arabic-rooted examples that the translator can resort occasionally to transliteration, definition, or

Al-Sofi, B. B. M. A., \& Abouabdulqader, H. (2020). Bridging the gap between translation and culture: towards a cultural dimension of translation. International Journal of Linguistics, Literature and Culture, 6(1), 1-13. https://doi.org/10.21744/ijllc.v6n1.795 
paraphrasing strategies of such terms in order to preserve the intended meanings. This idea supports Ghazala (2008) thought that meaning is not only in words but it is also in culture, grammar, style, and sound.

Table 2

Examples of Arabic terms that have no equivalents in English

\begin{tabular}{|c|c|c|}
\hline Arabic word & Transliteration & Implied meaning \\
\hline سَحُورْ & /sahuurun/ & The food that is eaten before dawn to be ready for fasting \\
\hline 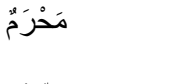 & /mahramun/ & $\begin{array}{l}\text { The person who should accompany his family while } \\
\text { traveling anywhere. }\end{array}$ \\
\hline التَتِدهُُ & /attayатити/ & $\begin{array}{l}\text { Dry ablution with the dust when there is no water for } \\
\text { prayers ablution. }\end{array}$ \\
\hline الأذَانُ & laladhanul & Calling for the prayers \\
\hline العِرْضُ & lalirdhul & $\begin{array}{l}\text { "A male's honor in protecting female members of his } \\
\text { family, possessions, and other people he is responsible for" } \\
\text { (Kashgary, 2011). }\end{array}$ \\
\hline
\end{tabular}

Similarly, the following examples carry contextual meanings and are translated oppositely as cultural differences may necessitate some adjustments. The idiom 'He was hungry for knowledge' was metaphorically used to indicate the intellectual eagerness to knowledge. The term 'thirsty' عاطش /a'atesh/ replaces the term 'hungry' جائع/ayee/ and translated as كان متعطناً للمعرفة/kana mota'atishan lil ma'arifati/. Likewise, in 'He ate the soup', the word 'ate' أكل 'akala/

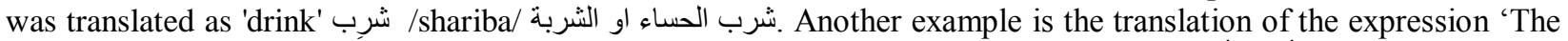
news warmed my heart'. It this case the term 'warm' was domesticated as 'cold' الأخبار أتلجت صدري ابري /alakhbar athlajat sadri/. Such domestication process carries cultural and ecological context as coldness is common and preferred in Arab countries because of high temperature, while warmth is preferred and glorified in Western cultures, and both have positive signs of cordiality and pleasant feelings of happiness.

Religion also plays a great role in the translation process. For example, some English expressions are communicatively translated into Arabic bearing in mind Venuti (1995), the domestication process that is related to religious background and the teachings of Islam. Hassan (2014) indicated that "allusion from the Holly Qura'n is used to compensate for the metaphor in the ST" (p. 43). The first example is the English saying "Don't put your head in the

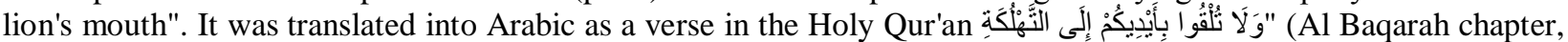
verse 195) /wala tolko bi aidikom ila attahlokati/ which means "and do not cast into destruction with your own hands". It is an advice not to deliberately place yourself in a dangerous or risky situation. The second example is "Treat women kindly", which was translated into Arabic considering the prophetic hadith of the Messenger Mohammed (pbuh) as

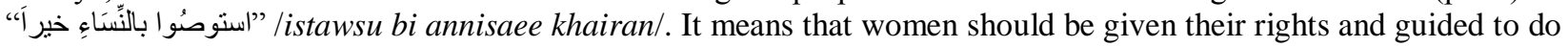
well rather than being oppressed. Another example is the saying "He who cheats belongs not to us". It was translated into Arabic based on the prophetic hadith "من غَثنا فليسنَ مِنَّا /man ghashana falaisa minnal. It denotes that the one who practices cheating in any aspect of daily life is not a Muslim. Another example is the English saying "Charity begins at home". It was rendered into the Arabic saying "الأقرُبُونَ أوْلى بالمعْروف /alakrabouna awla bil ma'aroufil depending on the Islamic background. As Arab countries are collectivistic, it refers that the first responsibility is to help close people in your family before thinking of helping others who live further away. Another example is the saying 'address people in the language they can understand'. This English saying is translated into Arabic in the form of a prophetic saying 'خاطبوا الناس على قدر عقو لهم' /khatibu annasi ala kadri okolehem/. 'To err is human' is also translated into Arabic as a prophetic hadith ' 'كل ابن آدم خطاءٌ 'kolu ibno Adama khatta'a/ which means that nobody is perfect or faultless. Obviously, the above-mentioned examples show the significance of considering cultural approximation for creative translation. They also prove the crucial importance of rendering the intended meaning of the translated terms or expressions, rather than the literal meaning of separate words. This is consistent with House (2014) assertion that translation is not only a linguistic act; it is also a cultural one. 
Table 3

Examples of English expressions that are translated based on religious background

\begin{tabular}{|c|c|c|c|}
\hline English saying & Implied meaning & Arabic translation & Arabic transliteration \\
\hline $\begin{array}{l}\text { "Don't put your head in } \\
\text { the lion's mouth". }\end{array}$ & $\begin{array}{l}\text { Not to deliberately place yourself } \\
\text { in a dangerous or risky situation. }\end{array}$ & 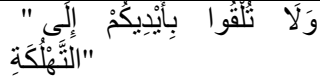 & $\begin{array}{l}\text { /wala tolko bi aidikom } \\
\text { ila attahlokati/ }\end{array}$ \\
\hline "Treat women kindly". & $\begin{array}{l}\text { Not to oppress women but rather } \\
\text { give them their rights and guide } \\
\text { them to do well. }\end{array}$ & "استوصُو ا بالنَّسَاءِ خير آ" & $\begin{array}{l}\text { /istawsu bi annisaee } \\
\text { khairan/ }\end{array}$ \\
\hline $\begin{array}{l}\text { "He who cheats belongs } \\
\text { not to us". }\end{array}$ & $\begin{array}{l}\text { The one who practices cheating in } \\
\text { any aspect of our daily life is not a } \\
\text { Muslim. }\end{array}$ & "من غشَنَا فليسَ مِنّا" & $\begin{array}{l}\text { Iman ghashana falaisa } \\
\text { minnal }\end{array}$ \\
\hline "Charity begins at home". & $\begin{array}{l}\text { The first responsibility is to take } \\
\text { care of the needy and close people } \\
\text { in your family before thinking of } \\
\text { helping others who live further } \\
\text { away. }\end{array}$ & "الأقَربُونَ أوْلى بالمعروفِ" & $\begin{array}{l}\text { /alakrabouna } \\
\text { bilma'aroufl }\end{array}$ \\
\hline
\end{tabular}

In the same way, idioms and expressions are phrases and sentences that do not mean exactly what the words say. Even if one knows the meaning of every word in the idioms or expressions, he/she may not understand their meanings as they are culturally based and reflect the use of the language by the native speaker. Such expressions reflect connotative meanings and bear cultural dimensions with greater significance that is beyond their literal meanings. In other words, the apparent literal denotative meaning of the target expression is completely different from its connotative meaning. Hence the role of the translator is to "sense the cultural elements embedded in the text and consider them in the transfer" (Hassan, 2014). Regarding this, the translation of idiomatic expressions is also another evidence of the importance of bridging the cultural gap in translation. They have a purely cultural specificity and may not be understood outside their context and intended meaning.

What follows are some idiomatic culture-bound expressions whose meanings are figurative. They are not fully predictable from their denotative meanings. For example, it sounds impractical to render the literal meaning of this

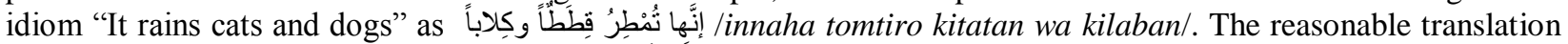

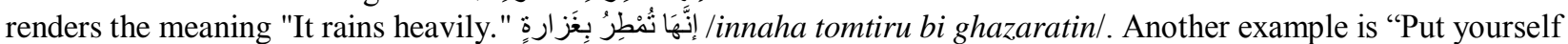

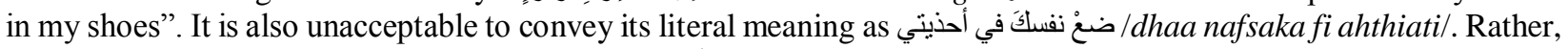
it means 'consider yourself in my position' ضنح نفسكَ في موقفي/dhaa nafsaka fi mawgifil. Another example is the English

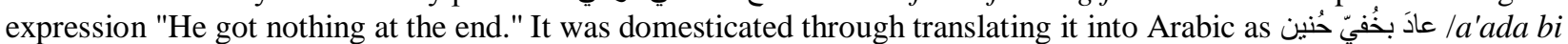
khoufai Honain/ "He came back with Honain's shoes" which has a historical background in Arabic culture.

Another example is the idiom "dead to the world" which does not convey the implied meaning if it is literally translated as it is widely used to describe a person who sleeps very deeply. Similarly, the literal translation of the idiom 'great gun' does not make sense as it refers to a very important person تخصية مهمة/shakhsiaton mohimah/. Another example is the idiom 'fat cat' رجل أعمال ثري/rajolo a3malin thari/ which describes a wealthy and powerful person, especially a businessman or politician. Hence, such examples are difficult to translate literally or word for word because they make no sense in conveying the implied meaning. What is needed is to delve deeper into the cultural equivalent with the aim of rendering the meaning of the message into the target people.

Table 4

Examples of English idiomatic expressions that are translated into Arabic semantically

\begin{tabular}{|c|c|c|c|}
\hline English proverb & Literal translation & Intended meaning & Arabic transliteration \\
\hline "It rains cats and dogs." & إنها تمطرُ قططاً و كلاباً & It rains heavily. & $\begin{array}{l}\text { linnaha tomtiru bi } \\
\text { ghazaratin/ }\end{array}$ \\
\hline $\begin{array}{l}\text { "Put yourself in my } \\
\text { shoes." }\end{array}$ & ضـْْ نفسكَ في أحذيتي. & $\begin{array}{l}\text { Consider yourself in my } \\
\text { position. }\end{array}$ & Idhaa nafsaka fi mawgifil \\
\hline $\begin{array}{l}\text { "He got nothing at the } \\
\text { end." }\end{array}$ & رجع بدونٍ أي شيء. & He came back with nothing. & la'ada bikhoufai Honain/ \\
\hline
\end{tabular}

Al-Sofi, B. B. M. A., \& Abouabdulqader, H. (2020). Bridging the gap between translation and culture: towards a cultural dimension of translation. International Journal of Linguistics, Literature and Culture, 6(1), 1-13. https://doi.org/10.21744/ijllc.v6n1.795 
The translation of the following famous examples supports the idea of the importance of translating their intended meaning rather than the denotative meanings of the separate words. The first example is "break the ice" in which its literal meaning in Arabic is اكُسِرِ الثَّجَ /iksiri athalja/ which does not convey the intended meaning. Rather, it aims to reduce the unfamiliarity and pave the way for something to take place. The second example is "He looks blue" in

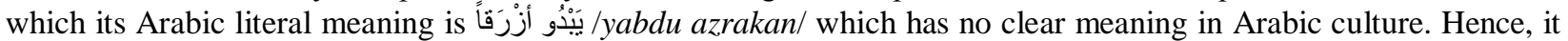
helps to translate its meaning as "he looks sad or unhappy". The third example is "She is in the clouds" in which its literal translation is هي في النّحاب/hia fi assahabil. It does not make sense in Arabic and seems obscure. The meaning that should be translated is that she is thinking about something. The fourth example is "He is on the cloud nine" which

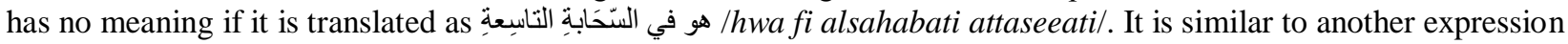
which is "to walk on air". Their intended meaning is that the person is extremely happy and excited, rather than the literal meaning 'living there in the cloud nine or really walking on air'. Another point is that western culture glorifies number nine (e.g. the cat has nine lives), while Arab culture praises number seven (the cat has seven lives) as it is related to religious beliefs (the number of skies, earths, days, etc.). The fifth example "I will go banana" does not make sense if it is literally translated into Arabic as سأصبحُ موزةً /sa'aosbihu mawzatan/. Rather, its intended meaning is 'I will

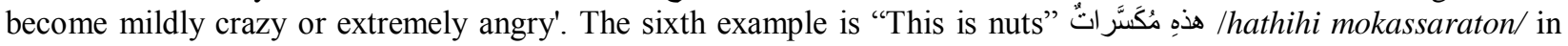
which its literal translation into Arabic has no meaning. What is required is to translate its connotative meaning as 'what you are doing is something strange or silly'. The seventh example is "It is a piece of cake". It has no meaning if translated literally in the same way as إنها قطعةٌٌ من كعكة /innaha kita'aton min ka'akatin/. Rather, it has a different meaning that should be translated into Arabic as 'This matter is very easy to be done or performed'.

The eighth example is "He lives a dog's life". The literal meaning of this idiom in Arabic is عَعِشُ عِيشَة الكَلبِ lya'aeeshu ishata alkalbi/. It cannot be translated as so. Rather, it bears the meaning that 'He lives a boring life full of anxiety and problems'. The ninth example is "He was born with a silver spoon in his mouth". This idiom sounds

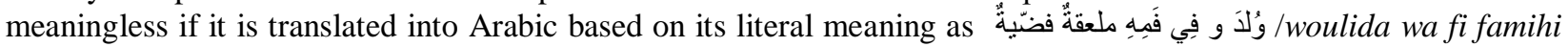
mila'akaton fidhiaton/. Rather, it has a connotative meaning that he was born into a rich family with inherited wealth. The last example is "I wasn't born yesterday". The connotative meaning that should be translated into Arabic is 'I am not extremely foolish, naive, or easily deceived to the extent you expect' rather than its denotative meaning as الأمس /lastu ibna alamsi/. It can be stated that the intended meaning of the examples cited above is unattainable and cannot be realized from the denotative meanings of the separate words. This is in agreement with Ghazala (2008), who view that what should be translated is "meaning, nothing else but meaning" (p. 3). In this sense, the translator can also employ 'cultural approximation' in which s/he can approximate in rendering the meaning of the words and terms of the source text taking into account the intended meaning.

Table 5

Examples of English expressions that are translated based on their connotative meanings

\begin{tabular}{|c|c|c|c|}
\hline English proverb & Implied meaning & $\begin{array}{l}\text { Arabic literal } \\
\text { translation }\end{array}$ & Arabic transliteration \\
\hline "Break the ice" & $\begin{array}{l}\text { Reduces the unfamiliarity or to } \\
\text { start and pave the way for } \\
\text { something to take place. }\end{array}$ & اكُعسبرِ الثَلجَ & laksiri athaljal \\
\hline "He looks blue" & He looks sad or unhappy. & يَيْذُو أَزْرَقَاً & /hwa yabdu azrakan/ \\
\hline "She is in the clouds" & She is thinking about something. & هي في السّحابٍ & Ihia fi assahabil \\
\hline "He is on the cloud nine" & $\begin{array}{l}\text { the person is extremely happy and } \\
\text { excited, }\end{array}$ & هو في الستّحابِة التاسعةِ & $\begin{array}{l}\text { Ihwa fi alsahabati } \\
\text { attaseeatil }\end{array}$ \\
\hline "I will go banana". & $\begin{array}{l}\text { I will become mildly crazy or } \\
\text { extremely angry'. }\end{array}$ & سأصبحُ موزةً & /sa'aosbihu mawzatan/ \\
\hline "This is nuts" & $\begin{array}{l}\text { What you are doing is something } \\
\text { strange or silly. }\end{array}$ & هذهِ مُكَسَّرَ اتُّ & /hathihi mokassaraton/ \\
\hline "It is a piece of cake." & This matter is very easy. & إنها قطعةً من كعكةٍ & $\begin{array}{l}\text { linnaha kita'aton min } \\
\text { ka'akatin/ }\end{array}$ \\
\hline "He lives a dog's life." & $\begin{array}{l}\text { 'He lives a boring life full of } \\
\text { anxiety and problems'. }\end{array}$ & يَعيشُ عِيشَة الكَلب & $\begin{array}{l}\text { lya'aeeshu ishata } \\
\text { alkalbil }\end{array}$ \\
\hline $\begin{array}{l}\text { "He was born with a silver } \\
\text { spoon in his mouth." }\end{array}$ & $\begin{array}{l}\text { He was born into a rich family } \\
\text { with inherited wealth. }\end{array}$ & وُلَّد و فِي فَفِهِ ملعقةٌ فضَّيةٌ & $\begin{array}{l}\text { /woulida wa fi famihi } \\
\text { mila'akaton fidhiaton/ }\end{array}$ \\
\hline
\end{tabular}


"I wasn't born yesterday." 'I am not extremely foolish, naive, or easily deceived to the extent you expect'

Proverbs are an important part of every culture and they encapsulate some underlying ideas, principles, beliefs, and values of a given culture. As they are challenging and bear cultural presuppositions, the conventional interpretations of the following proverbs differ from the denotative meaning of their separated words. The literal meanings of the following proverbs mismatch with their message. Therefore, they are domesticated and rendered into Arabic in the form of poetic verses considering pragmatic equivalent and communicating the overall meanings that correspond with their intended meanings. The first proverb 'East or West, home is the best' is rendered into Arabic in the form of a

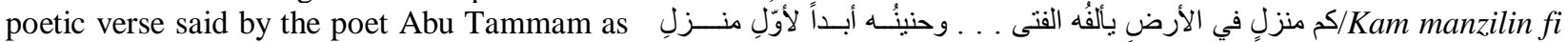
alardhi ya'alafahu alfata... wahaninohu abadan li awwali manzili/ (Ghazala, 2008). It denotes that homeland is incomparable and better than any other place. The second example is the English idiom "no gains without pains" or "no pain, no gain" which means that suffering is necessary and that nothing is achieved easily without suffering or

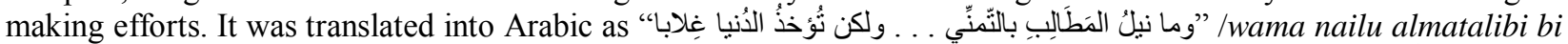

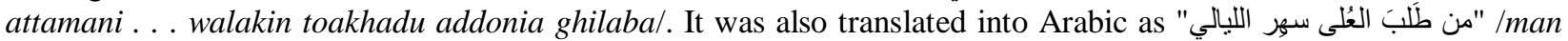
talaba alola sahira al-layali/. It denotes that people should be willing to endure some inconvenience or discomfort in order to achieve worthwhile goals. Another example is the English saying "A good deed is never lost". It is rendered

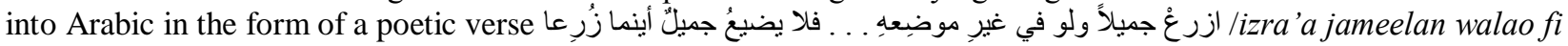
ghairi mawdheihi... fala yadheeo jameelon aynama zoria'al. It conveys a moral lesson that good deeds should be sown anytime anywhere for anyone and they are never lost or forgotten by God and people as well. Another famous saying is "A man is known by the company he keeps". It might be difficult to convey its meaning depending on the translation of the separate words. Hence, the meaning was approximated and translated into Arabic as a poetic verse /aan almari la tasa'al wasal an kareenihi.... fakoli kareenin bilmokarani yaktadil. It means that if you want to know about a person's actions and morals, ask about the friends he accompanies. It was also translated into Arabic as a prophetic Hadith "المر عُ على دينِ خليلِ فلينظر أحدُكم من يخالِل ala deeni khaleelehi ...falyandhor ahadokom man yokhalell. It stimulates people to choose good people to accompany as the man is valued or known by the morals of his friends. Another example is the English proverb: "love me, love my dog".

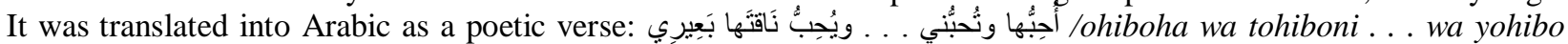
nakataha baeeri/ (Ghazala, 2008). It denotes that people should be willing to accept everything about their friends unconditionally. In other words, if you love your friend, you should accept his/her behaviors as well. At this point, 'the camel', an important part of Arab life from the early times, is put in the place of dog which is important in western life.

Likewise, the English proverb 'After black clouds, clear weather' is similar to another one "every cloud has a silver lining'. Both are translated in the same way into a verse in the Holy Quran as "إن مع العسر يسرا!" "Indeed, hardship is followed by ease" (Al-Inshirah chapter, no 94, verse 5). Similarly, they are translated in the form of a poetic verse dhakat falamma astahkamat halakatoha forijat ...... wa konto adhonoha la tofraju/. Both translations convey a moral lesson that we should be patient as after difficult times, easy ones come directly. Likewise, the English proverb 'A little pot is soon hot' is translated into Arabic in the form of common saying as /alilmu fi alsighari kanaqshi ala alhajari/. It carries a meaning that seeking knowledge at a young age is like engraving on a stone. It means that what is learned earlier is hard to lose later or easily. It is an advice for parents to encourage their children to work hard in their early childhood. Similarly, the English proverb 'When it rains, it pours' was translated into a common Arabic saying as المصائب تأتي تباعاً /almasayebu ta'ati tiba'an/. It is used to convey the message that difficult or bad things always happen at the same time. In the same way, the English saying 'It is very hard to please everybody' is translated into Arabic as إرضاء الناس غاية لا تدرك/irda'a annasi ghayaton la todrak/. It denotes that pleasing everybody cannot be achieved as everyone has his/her needs and benefits and that will impede achieving your real goals.

Table 6

Some examples of English proverbs that are translated into Arabic as poetic verses

\begin{tabular}{|c|c|c|c|}
\hline English proverb & Implied meaning & Arabic translation & Arabic transliteration \\
\hline $\begin{array}{l}\text { "East or West, home } \\
\text { is the best" }\end{array}$ & $\begin{array}{l}\text { Home country is ideal and } \\
\text { better than any other place. }\end{array}$ & 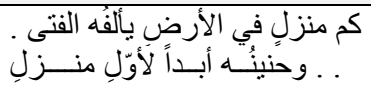 & $\begin{array}{l}\text { /Kam manzilin fi alardhi } \\
\text { ya'alafahu alfata }\end{array}$ \\
\hline
\end{tabular}

Al-Sofi, B. B. M. A., \& Abouabdulqader, H. (2020). Bridging the gap between translation and culture: towards a cultural dimension of translation. International Journal of Linguistics, Literature and Culture, 6(1), 1-13. https://doi.org/10.21744/ijllc.v6n1.795 


\begin{tabular}{|c|c|c|c|}
\hline "no pain, no gain" & $\begin{array}{l}\text { Nothing is achieved easily } \\
\text { without making effort }\end{array}$ & 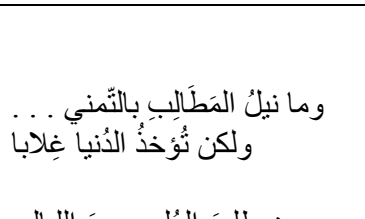 & $\begin{array}{l}\text { wahaninohu abadan li } \\
\text { awwali manzili/ } \\
\text { /wama nailu almatalibi } \\
\text { biattamani... walakin } \\
\text { toakhadu addonia ghilabal }\end{array}$ \\
\hline $\begin{array}{l}\text { "A good deed is } \\
\text { never lost". }\end{array}$ & $\begin{array}{l}\text { Good deeds should be } \\
\text { sawn anywhere for anyone } \\
\text { and they are never } \\
\text { forgotten by God and } \\
\text { people as well. }\end{array}$ & 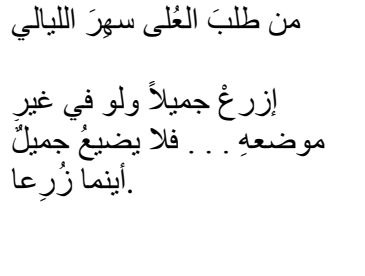 & $\begin{array}{l}\text { Iman talaba alola sahira al- } \\
\text { layali/. } \\
\text { lizra'a jameelan walao fi } \\
\text { ghair mawdheihi... fala } \\
\text { yadhee jameelon aynama } \\
\text { zoria'al }\end{array}$ \\
\hline $\begin{array}{l}\text { "A man is known by } \\
\text { the company he } \\
\text { keeps". }\end{array}$ & $\begin{array}{l}\text { If you want to know about } \\
\text { a person's actions and } \\
\text { morals, ask about the } \\
\text { friends he accompanies. }\end{array}$ & 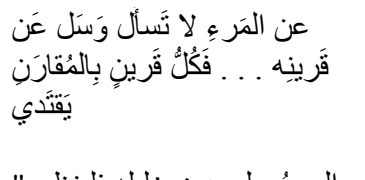 & $\begin{array}{l}\text { laan almari la tasaal wasal } \\
\text { an kareenihi.... fakol } \\
\text { kareenin bilmokarani } \\
\text { yaktadil }\end{array}$ \\
\hline $\begin{array}{l}\text { "Love me, love my } \\
\text { dog". }\end{array}$ & $\begin{array}{l}\text { If you love me, you need } \\
\text { to love or accept the } \\
\text { people and things that are } \\
\text { part of my life. }\end{array}$ & 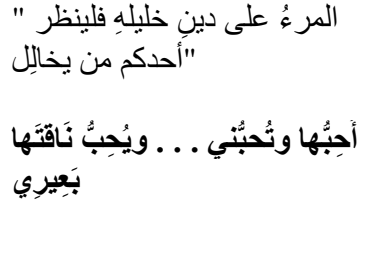 & $\begin{array}{l}\text { lalmarau ala deen } \\
\text { khaleelehi falyandhor } \\
\text { ahadokom man yokhalell } \\
\text { /ohiboha wa tohiboni wa } \\
\text { yohibo nakataha baeeri/ }\end{array}$ \\
\hline
\end{tabular}

To sum up, it should be noted that there are relevance and logical connection between the messages of the selected examples adduced above and the conveyed ones in the attached translation. Moreover, such examples are difficult to be understood out of contexts, or simply from the meaning of their separate words. Rather, they are translated bearing in mind the equal value, the context, the implied meaning, and resorting to different translation strategies (addition, omission, paraphrasing, borrowing, transliteration, approximation, etc.). Such effective strategies are used to overcome the obstacles that the translators face as sometimes there are no target equivalents that match the source text idioms or expressions and vice versa. This also proves that translation is not only a linguistic activity but a cultural one as well. This is in accordance with Torop (2002) equation of culture and translation "culture is a translation, and also that translation is culture" (p. 603). Moreover, translating the texts that are deeply embedded in the culture cannot be done in isolation from their cultural contexts; otherwise, it distorts the text characteristics and the intended meanings. Hence, the translation of the above examples supports Badawi's (2008) and Al-Dosari's (2013), ideas that translators should not limit themselves to bilingualism. Rather, they should consider the involvement of the cultural side of the source and target texts. Consequently, the translation of such terms, expressions, idioms, and proverbs might not be achieved away from their culture. This view supports the hypothesis posed at the beginning of the study that culture matters and plays a crucial role in the creation of good translation and that disregarding its accurate transfer into the target text and audience may lead to failure in conveying the intended message.

It denotes that the importance of bridging the cultural gap lies in its role to convey the intended meaning and hence its contribution to the success of the translation process. Hence, translators should be fully immersed in both cultures in order to convey the meaning and cultural equivalence. Otherwise, they will be at a loss with culturally-laden texts. Taken together, it seems convenient to suggest that cultural competence needs to be developed alongside a linguistic one as together they lead to creative translation.

\section{Conclusion}

The translation is a demanding process that is not merely a matter of transferring words. Rather, it is a matter of language-and-culture connection. This study has shed light on the importance of bridging the cultural gap in the translation process. It was elicited that translation should also be approached from a cultural standpoint. It is inevitably more than a linguistic activity; it is fundamental to focus on language and culture as they have twofold relation 
especially with the new shift towards the culture-and-translation bond which has become one of the topics that have been increasingly emphasized daily.

Altogether, the findings of the study indicate that a lack of cultural knowledge in a translated script might lead to a distorted and linguistically unacceptable text. In particular, the findings indicate that translation goes beyond the linguistic system of a particular language as it focuses not only on rendering words/texts from one language into another but also on conveying the different cultural aspects. Translators should smooth over the cultural gap through familiarizing themselves with both the source and target cultures. Additionally, there is an important correlation between translation and intercultural communication in which the two concepts have the same goal of conveying knowledge through either professional translation or using the language to communicate successfully with others. Moreover, translation is a creative process that is gradually developed and greatly influenced by the accumulated experience and the degree of complexity of the texts the translator is working with. In this perspective, it should be borne in mind that translators cannot be fully competent in all the fields they deal with. They need to acquire the capacity to approximate the subject areas to such an extent that they can enable and facilitate easy and flawless understanding among the average reader as well as among the experts (Neubert, 2000). Finally, competent translators should get acquainted with the culturally oriented shift of the translation process. They should be concerned with widening their horizons and be fully aware of linguistic aspects along with the awareness of the source and target cultures.

To conclude, the results gleaned from the present study could be of great value to stakeholders in the field of translation, including linguists, foreign language learners, translation program designers, and translators as it touched the neglected idea of the importance of being not only bilingual but also bicultural. They also suggest that translation colleges and programs should include modules that familiarize students with the intercultural dimensions of discourse as a means of bridging the cultural gap in the translation process. As a consequence, one essential point raised in the present study is that these curricula need to make culture a central component in TS.

Conflict of interest statement and funding sources

The authors declared that they have no competing interests.

Statement of authorship

The authors have a responsibility for the conception and design of the study. The authors have approved the final article.

\section{Acknowledgments}

The authors would like to thank the reviewer for their consideration of the further process of the present paper. Thanks to the editor of IJLLC for the valuable support, time as well as advice.

Al-Sofi, B. B. M. A., \& Abouabdulqader, H. (2020). Bridging the gap between translation and culture: towards a cultural dimension of translation. International Journal of Linguistics, Literature and Culture, 6(1), 1-13. https://doi.org/10.21744/ijllc.v6n1.795 


\section{References}

Al-Dosari, H. (2013). Effects of Using Culture-laden Texts on Culture-specific Translation Skills in Arab Students. The Coastal Review: An Online Peer-reviewed Journal, 4(1), 2. https://doi.org/10.20429/cr.2013.040103 Al-Qurashi, A. (2004). Problems of sight translation (Doctoral dissertation, Yarmouk University).

Badawi, M. F. (2008). Investigating EFL Prospective Teachers' Ability to Translate Culture-Bound Expressions. Online Submission.

Bahumaid, S. (2010). Investigating cultural competence in English-Arabic translator training programs. Meta: Journal des traducteurs/Meta: Translators' Journal, 55(3), 569-588. https://doi.org/10.7202/045078ar

Bassnett, S. (1990). Translation, history, and culture. Pinter Pub Ltd.

Bell, R. T., \& Candlin, C. (1991). Translation and translating: Theory and practice (Vol. 298). London: Longman.

Byram, M., \& Risager, K. (1999). Language teachers, politics and cultures. Multilingual Matters.

Darwish, A. (2001). Transmetrics: A formative approach to translator competence assessment and translation quality evaluation for the New Millennium. Retrieved March, 15, 2012.

Elzubier, E. A. (2012). A framework for developing the translation competence of Sudanese student translators. Journal of Faculty of Arts, Omdurman Islamic University, 4 (4): 1-15.

Fenyő, S. S. (2005). The Translator's Cultural Competence. European Integration Studies, 4(2), 61-72.

Gerding-Salas, C. (2000). Teaching translation: problems and solutions. Translation Journal, 4(3), 328-334.]

Ghazala, H. (2008). Translation as Problems and Solutions-A Textbook for University Students and Trainee Translators (Special Edition).

Hassan, B. E. A. (2014). Between English and Arabic: A practical course in translation. Cambridge Scholars Publishing.

Hatim, B. (1990). Mason, lan. Discourse and the Translator, 125.

Hermans, T. (1999). Translation in Systems, Manchester: St.

House, J. (Ed.). (2014). Translation: a multidisciplinary approach. Springer.

Kashgary, A. D. (2011). The paradox of translating the untranslatable: Equivalence vs. non-equivalence in translating from Arabic into English. Journal of King Saud University-Languages and Translation, 23(1), 47-57. https://doi.org/10.1016/j.jksult.2010.03.001

Komissarov, V. N. (1991). Language and Culture in Translation: Competitors or Collaborators? traduction, terminologie, redaction, 4 .

Liu, X. (2018). International Publicity Translation of Tourism Culture in Central China from the Perspective of Skopos Theory. International Journal of Linguistics, Literature and Culture, 4(2), 1-8.

Muamaroh, M. (2008). THE RELATIONSHIP BETWEEN CULTURE AND TRANSLATION.

Neubert, A. (2000). Competence in language, in languages, and in translation. Benjamins Translation Library, 38, 318.

Newmark, P. (2001). A Textbook of Translation. Shanghai: Shanghai Foreign Language Education Press.

Nida, E. A. (1964). Toward a science of translating: with special reference to principles and procedures involved in Bible translating. Brill Archive.

Orozco, M., \& Hurtado Albir, A. (2002). Measuring translation competence acquisition. Meta: journal des traducteurs/Meta: Translators' Journal, 47(3), 375-402. https://doi.org/10.7202/008022ar

Pym, A. (1992). Translation and text transfer. An Essay on the Principles of.

Pym, A. (2010). Exploring Translation Series. London and New York.

Salehi, M. (2012). Reflections on culture, language and translation. Journal of Academic and Applied Studies, 2(5), 76-85.

Schäffner, C. (2003). Translation and intercultural communication: Similarities and differences.

Sebokova, S. (2010). Comparing translation competence. Brno: Masaryk University.

Sugyaningsih, R. S., \& Mardiana, R. S. R. (2017). Indonesian text about Javanese culture into English text: most common translation strategies on the perspective of Vinay and Darbelnet. International Journal of Linguistics, Literature and Culture, 3(3), 10-18.

Suryasa, I. W., Sudipa, I. N., Puspani, I. A. M., \& Netra, I. (2019). Translation of Krsna text and ideology. International journal of social sciences and humanities, 3(1), 36-47. https://doi.org/10.29332/ijssh.v3n1.251

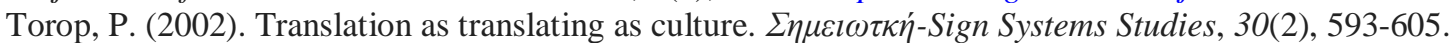

Venuti, L. (1995). The Translator's Invisibility. London and New York. Routledge. New York Times “California Seeks to Stop the Use of Child Medical Interpreters, Published: October, 30, 2005.

Wafa, L. E. M. A. H. (2014). Advanced English-Arabic translation: A practical guide. Edinburgh University Press. 
Yazıc1, M. (2007). Yazılı Ceviri Edinci. Ceviribilim. Istanbul: Multilingual Yayınları.

\section{Biography of Authors}

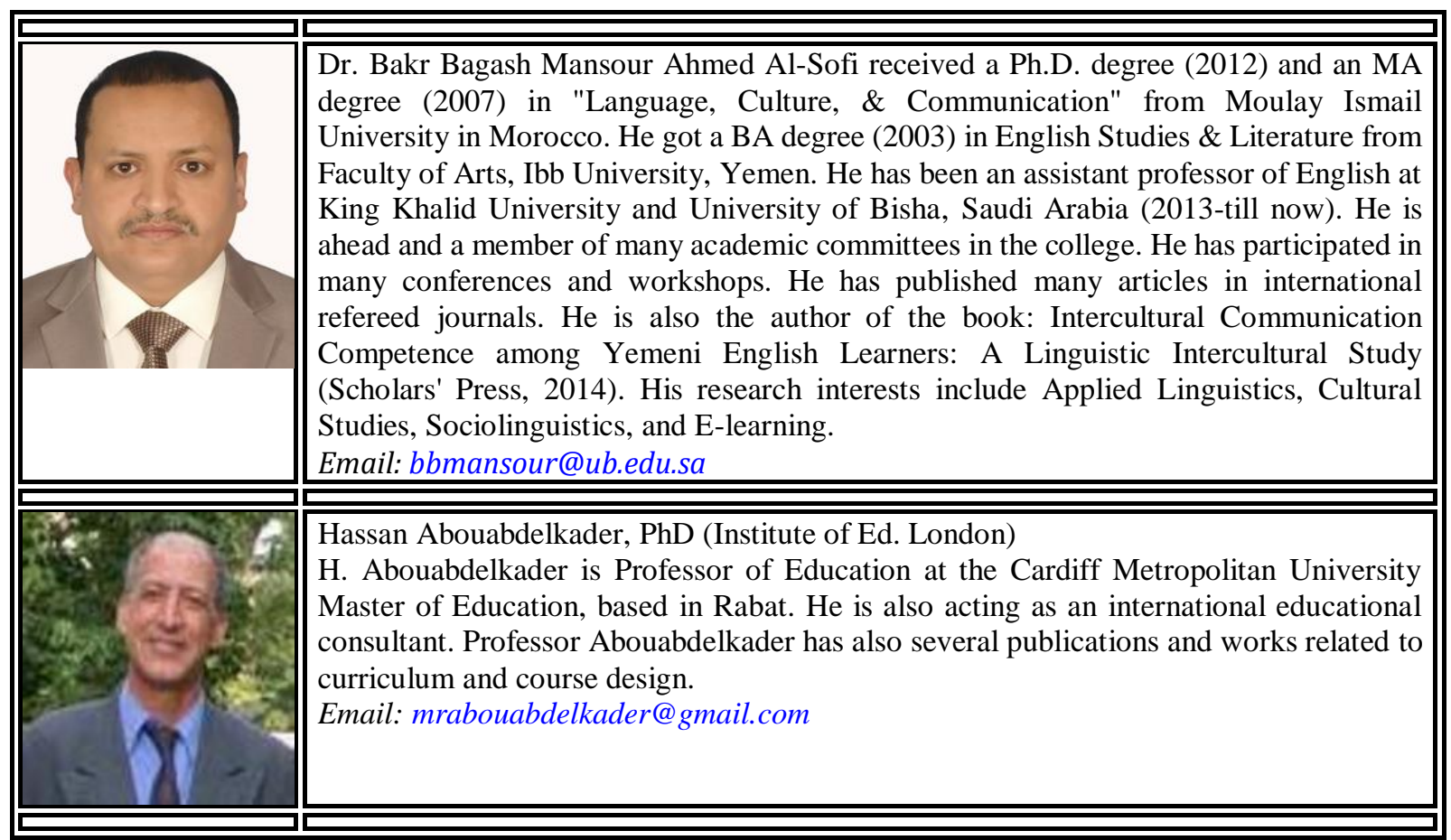

Al-Sofi, B. B. M. A., \& Abouabdulqader, H. (2020). Bridging the gap between translation and culture: towards a cultural dimension of translation. International Journal of Linguistics, Literature and Culture, 6(1), 1-13. https://doi.org/10.21744/ijllc.v6n1.795 